\title{
Study of domestic refrigerator temperature and analysis of factors affecting temperature: a French survey
}

\author{
Onrawee Laguerre*, Evelyne Derens, Bernard Palagos \\ Refrigeration Process Engineering Research Unit, Cemagref, BP. 44, 92163 Antony Cedex, France
}

Received 15 February 2001; received in revised form 20 April 2001; accepted 9 May 2001

\begin{abstract}
A survey was carried out in France from April to June 1999. Temperatures were recorded at three levels (top, middle and bottom) of the refrigerator compartment using a data logger. A questionnaire was filled in, enabling the following information to be obtained: characteristics of the family, characteristics of the refrigerator and the use conditions. One hundred and forty-three domestic refrigerators were surveyed, but due to various technical problems, only 119 sets of recorded temperatures were exploitable. The temperatures of the surveyed refrigerators were: average $6.6{ }^{\circ} \mathrm{C}$, minimum $0.9^{\circ} \mathrm{C}$ and maximum $11.4{ }^{\circ} \mathrm{C}$. Statistical analysis such as clustering and segmentation were used. It was found that the heterogeneousness of temperature inside each refrigerator seems to be dependent on the type. This study shows the influence of the use conditions on the temperature. No one factor exerts a single direct effect; a combination of the effects of all factors is observed. (C) 2002 Elsevier Science Ltd and IIR. All rights reserved.
\end{abstract}

Keywords: Domestic refrigerator; Temperature; Measurement; Parameter; Survey

\section{Etude sur les réfrigérateurs domestiques et analyse des facteurs influençant la température : enquête française}

\section{Résumé}

Une enquête a été réalisée en France durant les mois d'Avril et Juin 1999. Des températures ont été enregistrées à trois niveaux (haut, milieu et bas) du compartiment du réfrigérateur en utilisant un enregistreur de températures. A l'aide d'un questionnaire, les informations suivantes ont pu être obtenues : caractéristiques de la famille, caractéristiques du réfrigérateur et conditions d'utilisation. L'enquête a porté sur cent quarante quatre réfrigérateurs ménagers, mais pour divers problèmes techniques, seul 119 fichiers de températures ont pu être exploités. La température moyenne des réfrigérateurs est de $6,6^{\circ} \mathrm{C}$ (minimum $0.9^{\circ} \mathrm{C}$ et maximum $11.4^{\circ} \mathrm{C}$ ). Des analyses statistiques telles que l'arbre de classification et de segmentation ont été utilisées. L'étude a montré que l'hétérogénéité de température dans le compartiment d'un réfrigérateur dépend du type de réfrigérateur. L'influence des conditions d'utilisation sont mises en évidence. Le niveau de température des réfrigérateurs est le résultat de nombreuses interactions entre les différents paramètres et non d'un seul des paramètres en particulier. (C) 2002 Elsevier Science Ltd and IIR. All rights reserved.

Mots clés : Réfrigérateur domestique; Température; Mesure ; Paramètre ; Enquête

* Corresponding author. Tel.: + 33-140-966-121; fax: + 33-140-966-075.

E-mail address: onrawee.laguerre@cemagref.fr (O. Laguerre). 


\section{Introduction}

Consumer food safety depends on temperature control throughout all stages in the cold chain: production, transport, storage, retail display and domestic refrigeration. In spite of good hygiene and technological progress at equipment level, domestic refrigeration, which is not covered by regulations, is still a source of concern; some indications show that food is stored at temperatures that are too high. In spite of this observation, few studies have been carried out in domestic settings.

Our literature review on refrigerator temperature under real-use conditions shows that six surveys have been carried out worldwide. Information obtained in these surveys is shown in Table 1.

A laboratory testing of a refrigerator under controlled ambient conditions (temperature, velocity and humidity of air) in China [7] has shown that only $2.3 \%$ of domestic refrigerators operate with a temperature $<6{ }^{\circ} \mathrm{C}, 34.1 \%$ operate within $8-12{ }^{\circ} \mathrm{C}, 34.1 \%$ operate within $12-14^{\circ}$ and $29.5 \%$ operate at $>14{ }^{\circ} \mathrm{C}$.

It can be seen in Table 1 that in the French survey carried out in 1993 [3], the temperature in more than $70 \%$ of refrigerators is over $6{ }^{\circ} \mathrm{C}$ (mean refrigerator temperature according to the French standard). For highly perishable food such as meat and meat products (Table 2), the preservation temperature should not exceed $2-4{ }^{\circ} \mathrm{C}$, depending on the type of product. This confirms that food is stored at temperatures that are too high.

Other conclusions from these surveys are:

- A majority of surveyed participants were unable to state the temperature at which they attempted to operate their refrigerator $[2,5]$.

- Analysis of variance of mean refrigerator temperature revealed that the overall refrigerator temperature and the temperature in the middle and bottom are not statistically different [2].
- The ambient temperature does not exert an effect on the refrigerator temperature. Most people maintained a temperature of $17-23{ }^{\circ} \mathrm{C}$ in their homes and refrigerators are designed for use in these conditions [2].

- Few (15\% in the UK survey) or no (Northern Ireland and New Zealand surveys) families use a thermometer to control temperature [1,2].

- There was no correlation between the temperature setting and refrigerator temperature. It was found that for some refrigerators, in spite of setting at the coolest position, the temperature is still high $\left(>5^{\circ} \mathrm{C}\right)[1,2]$.

- Refrigerator temperature is influenced by a combination of factors $[1,2]$.

The first survey in France was carried out in 1993 and involved temperature measurement using a thermometer. The present study was carried out in order to update knowledge on preservation temperatures in domestic refrigerators and to implement a more precise measuring method. The objectives of our survey were firstly to monitor the air temperature inside the refrigerator under real-use conditions in France and secondly, to analyze the factors which have the greatest impact on refrigerator temperature.

\section{Survey method}

Our survey was carried out in collaboration with CREDOC (French Research Centre for the Study and Observation of Living Conditions); 143 refrigerators were surveyed in France from April to June 1999. The investigators interviewed a family representative and filled in the questionnaire. The data loggers, programmed to record the temperature every $2-8 \mathrm{~min}$, were located at the top, middle and bottom (just over the vegetable drawer) of the refrigerator compartment and were recovered 7 days

Table 1

Results obtained in domestic refrigerator temperature surveys $(\mathrm{T}=\mathrm{Top} ; \mathrm{M}=$ Middle; $\mathrm{B}=\mathrm{Bottom})$

Tableau 1

Résultats de la littérature sur les enquêtes réalisées sur le niveau de température dans les réfrigérateurs ménagers $(T=H a u t ; M=M i l i e u$; $B=$ Bas)

\begin{tabular}{|c|c|c|c|c|c|c|c|}
\hline Authors & Country & $\begin{array}{l}\text { Number of } \\
\text { samples }\end{array}$ & Measurement & $\mathrm{T}_{\min }$ & $\mathrm{T}_{\text {mean }}$ & $\mathrm{T}_{\max }$ & $\begin{array}{l}\% \text { Refrig. } \\
\mathrm{T}>\theta^{\circ} \mathrm{C}\end{array}$ \\
\hline Flynn et al. 1992 [1] & North Ireland & 150 & Thermometer (3 levels: T, M, B) & 0.8 & 6.5 & 12.6 & $71\left(T>5^{\circ} \mathrm{C}\right)$ \\
\hline James and Evans, 1992 [2] & U.K. & 252 & Data logger (3 levels: T, M, B) & -0.9 & 11.4 & 6.0 & $23\left(T>7^{\circ} \mathrm{C}\right)$ \\
\hline $\begin{array}{l}\text { National Institute of } \\
\text { Consumption, } 1993 \text { [3] }\end{array}$ & France & 102 & Thermometer (3 levels: T, M, B) & & & 14 & $70\left(T>6^{\circ} \mathrm{C}\right)$ \\
\hline Lezenne Coulander, 1994 [4] & The Netherlands & 125 & Thermometer & & & & $70\left(T>5^{\circ} \mathrm{C}\right)$ \\
\hline O'Brien, 1997 [5] & New Zealand & 50 & Thermometer (2 levels: T, B) & 0 & 4.9 & 11 & $60\left(T>4^{\circ} \mathrm{C}\right)$ \\
\hline Sergelidis et al. 1997 [6] & Greece & 136 & Thermometer & & & & $55\left(T>9^{\circ} \mathrm{C}\right)$ \\
\hline
\end{tabular}


Table 2

Preservation temperature of some food products to be maintained until consumption

Tableau 2

Température de conservation à maintenir jusqu'à la consommation de certains aliments

\begin{tabular}{ll}
\hline Temperature & Foodstuffs \\
\hline $0-2{ }^{\circ} \mathrm{C}$ & Fish and seafood \\
$+2{ }^{\circ} \mathrm{C}$ & Ground meat \\
$+4{ }^{\circ} \mathrm{C}$ & Various types of meat and meat preparations, \\
& sausage, chicken, fresh milk, cheese \\
$+5{ }^{\circ} \mathrm{C}$ & Eggs \\
$+8{ }^{\circ} \mathrm{C}$ & Stable meat products, dairy products \\
\hline
\end{tabular}

later. Due to several technical problems, only 119 temperature files were exploitable in our study.

The following information was obtained from the questionnaire:

- characteristics of participants: age, profession, income, number of family members, region;

- characteristics of the refrigerator: brand, type, height of the refrigerating compartment, temperature setting, refrigerating type (natural or forced convection), defrosting type (manual, semi-automatic, automatic);

- use conditions: near a heat source, built-in, room temperature and frequency of door openings per day.

\section{Statistical analysis}

In order to perform statistical analysis, the following tasks were carried out:

- Data preparation such as the coding of various data according to their nature, range establishment for each characteristic;

- Descriptive analysis making it possible to show the distribution of participant characteristics, refrigerators and use conditions;

- Multi-dimensional analysis such as crossed table, clustering and segmentation were used to analyse, discern and explain the relationship between parameters.

\section{Results obtained in the survey}

\subsection{Descriptive analysis}

\subsubsection{Characteristics of participants}

Some characteristics such as the number of family members are shown in Fig. 1. It can be observed that the number of members is 4 or less in the majority of households $(87 \%)$.

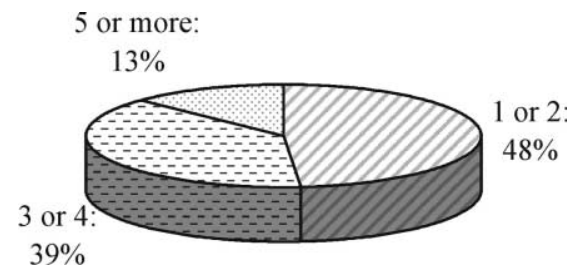

Fig. 1. Distribution of number of family members.

Fig. 1. Distribution du nombre de personnes au foyer.

\subsubsection{Refrigerator characteristics}

Fifty-four per cent of refrigerators have static refrigeration systems and $10 \%$ have ventilated ones. It was surprising to find that $36 \%$ of surveyed families did not know whether the refrigeration system was static or ventilated.

Some other characteristics such as the age and types of refrigerators are shown in Figs 2 and 3.

The setting of the refrigerator thermostat varies in different brands and models. To avoid all sources of confusion, the refrigerator setting, as a portion of the full scale, was reported for each refrigerator; the value varies from 0 to 1 . The distribution of temperature settings is shown in Fig. 4.

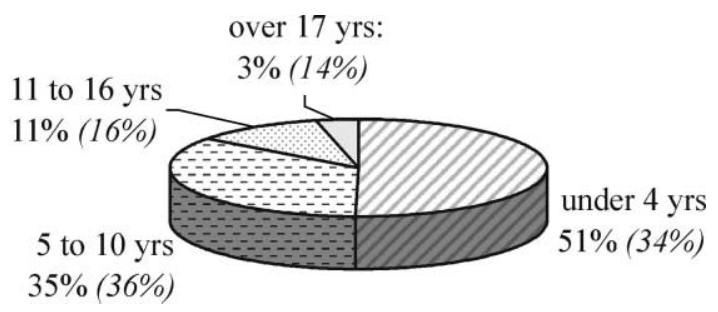

Fig. 2. Age of refrigerators. National statistic 1996.

Fig. 2. Age des réfrigérateurs. Statistique National 1996.

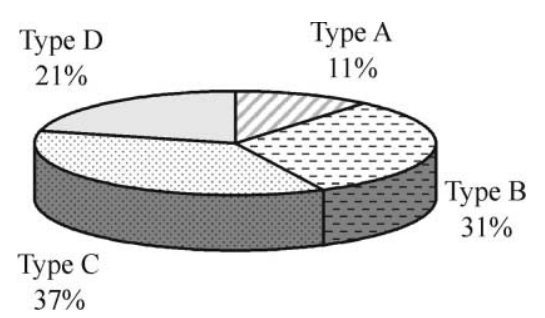

Fig. 3. Distribution of refrigerator type; Type A: top refrigerator (90 cm high); Type B: one door refrigerator; Type C: two doors, top freezer; Type D: two doors, bottom freezer.

Fig. 3. Distribution du type de réfrigérateur ; Type A: une porte (hauteur $90 \mathrm{~cm}$ ) ; Type B: une porte (hauteur $>90 \mathrm{~cm}$ ); Type $C$ : double porte, congélateur en haut; Type D: double porte, congélateur en bas. 


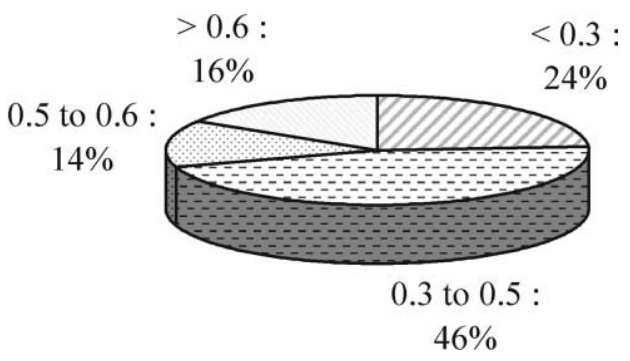

Fig. 4. Thermostat setting as a portion of full setting.

Fig. 4. Réglage du thermostat en proportion du réglage maximal.

\subsubsection{Use conditions}

It was found that $30 \%$ of refrigerators are located near a heat source (oven, dish-washing machine, etc.) and $14 \%$ are built-in. The number of door openings during breakfast, lunch, dinner and between meals was estimated in order to help the participants to determine the door-opening frequency per day. The distribution of the frequency of door openings is shown in Fig. 5.

\subsection{Refrigerator temperature}

Results obtained for the temperatures of 119 refrigerators (type B, classic single-door refrigerator)

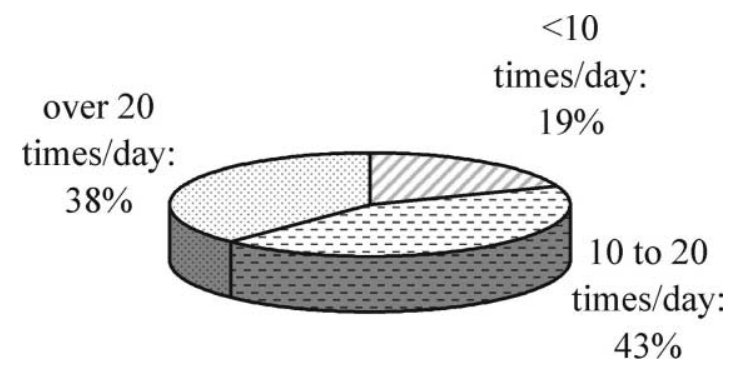

Fig. 5. Frequency of door openings.

Fig. 5. Fréquence d'ouvertures des portes.

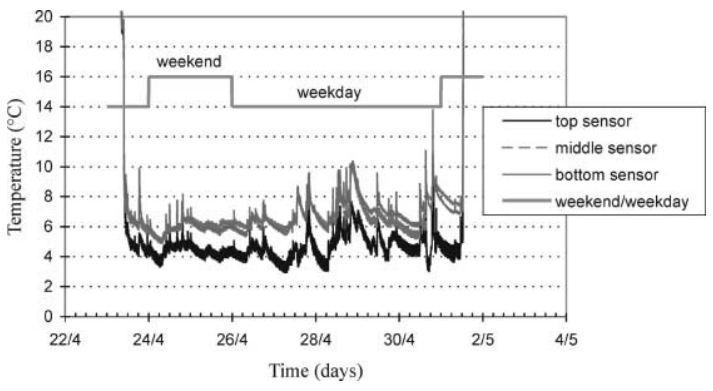

Fig. 6. An example of temperature recording over a 1-week period inside a type-B refrigerator (one-door refrigerator).

Fig. 6. Exemple de courbe de température à l'intérieur d'un réfrigérateur du type B enregistrée sur 7 jours. recorded over a 7-day period are shown in Fig. 6. It can be observed that the temperature recorded at the top is lower than those at the middle and the bottom. The peaks may be due to temperature regulation by the thermostat or to door openings. During the day of 28th and 29th, more peaks were observed and the mean temperature was higher; this may correspond to the shopping day during which the refrigerator is fuller than on other days.

For each refrigerator, $T_{\mathrm{t}}$ represents the mean temperature measured over a 7-day period at the top, $T_{\mathrm{m}}$ at the middle and $T_{\mathrm{b}}$ at the bottom of the refrigerating compartment. The global temperature $T_{\mathrm{g}}$ represents the mean value of $T_{\mathrm{t}}, T_{\mathrm{m}}$ and $T_{\mathrm{b}}$. Because of the limited number of sensors, the middle temperature was not systematically measured.

Fig. 7 and Table 3 show the distribution of global temperature of 119 refrigerators with $T_{\min }=0.9^{\circ} \mathrm{C}$, $T_{\max }=11.4{ }^{\circ} \mathrm{C}, T_{\text {average }}=6.6{ }^{\circ} \mathrm{C}$ and standard deviation $=2.3$. The average temperature of the population is between 6.2 and $7.0{ }^{\circ} \mathrm{C}$ (with $95 \%$ of confident level). Eighty per cent of surveyed refrigerators had a temperature above $5{ }^{\circ} \mathrm{C}$ which is the French standard for refrigerator temperature.

The variance test on the overall sample shows that there is no significant difference between $T_{\mathrm{t}}, T_{\mathrm{m}}$ and $T_{\mathrm{b}}$. However, the difference is significant when the test is applied to each refrigerator type separately as shown in Fig. 8 where the average values of $T_{\mathrm{t}}, T_{\mathrm{m}}$ and $T_{\mathrm{b}}$ are plotted as a function of refrigerator type. The most homogeneous temperature was observed for type A appliances, due to the small volume of the refrigerating compartment. The most striking difference was observed for type $\mathrm{D}$ appliances $\left(1.7^{\circ} \mathrm{C}\right)$ and this may be explained by a wide range of products (bottom and top of the range) of the same type.

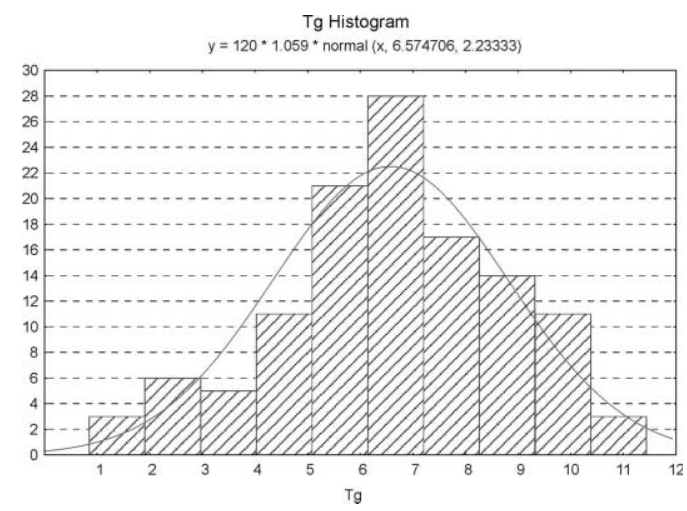

Fig. 7. Distribution of the overall temperature of 119 surveyed refrigerators.

Fig. 7. Distribution de la température globale de l'air dans 119 réfrigérateurs. 
Table 3

Distribution of the overall top, middle and bottom temperatures of refrigerators

Tableau 3

Distribution des températures globale, en haut, au milieu et en bas de réfrigérateurs

\begin{tabular}{lllllllll}
\hline$T\left({ }^{\circ} \mathrm{C}\right)$ & Number & Mean & S.D. & Min & Max & Median & Low quartile & High quartile \\
\hline$T_{\mathrm{g}}$ & $120^{\mathrm{a}}$ & 6.6 & 2.3 & 0.9 & 11.4 & 6.8 & 5.2 & 8.2 \\
$T_{\mathrm{t}}$ & 117 & 6.7 & 2.5 & -1.6 & 12.0 & 7.0 & 4.9 & 8.2 \\
$T_{\mathrm{m}}$ & 72 & 6.4 & 2.4 & -0.2 & 10.7 & 6.9 & 4.8 & 7.8 \\
$T_{\mathrm{b}}$ & 119 & 6.5 & 2.7 & -1.0 & 11.6 & 6.7 & 5.2 & 8.5 \\
\hline
\end{tabular}

a One recorded temperature without a questionnaire.

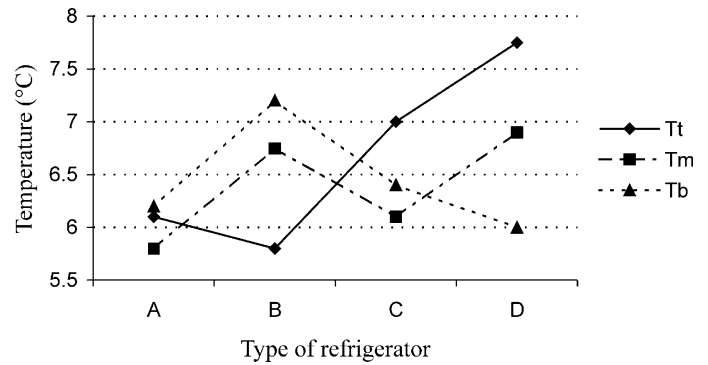

Fig. 8. Difference between temperatures measured at the top, middle and bottom of 4 types of refrigerator.

Fig. 8. Différence entre les températures mesurées en haut, au milieu et en bas, pour 4 types de réfrigérateur.

\subsection{Multidimensional analysis of factors affecting refrigerator temperature}

\subsubsection{Two-dimensional analysis (crossed table)}

This method was used in order to verify the relationship between factors (characteristics of refrigerator, use conditions and characteristics of participants) and between factor and overall temperature $\left(T_{\mathrm{g}}\right)$. It was found that there is no direct relationship between these, particularly in terms of temperature settings and refrigerator temperatures. $7 \%$ of refrigerators with high temperature settings still have a low temperature $\left(<2.5^{\circ} \mathrm{C}\right)$ while $6 \%$ of refrigerator which have low temperature settings, still have a high temperature $\left(>10^{\circ} \mathrm{C}\right)$. Analysis of the refrigerators located near heat sources did not enable conclusions to be drawn concerning this effect on temperature since the overall temperature varies from low to high. No built-in refrigerators had temperatures under $2.5{ }^{\circ} \mathrm{C}$. There is no relationship between the socioeconomic bracket of participants and refrigerator temperatures.

\subsubsection{Clustering}

The objective is to study the effect of consumer use conditions on the overall temperature. The clustering makes it possible to consider refrigerators with as many common characteristics as possible in the same group. Moreover, each group must have different common characteristics compared with the other groups, to the greatest extent possible. Four factors which may have a major influence on temperature were used in the analysis: built-in (BI), heat source (HS), temperature setting (TS), frequency of door openings (FDO).

This analysis gives rise to eight groups of refrigerators. The values of overall temperature $\left(T_{\mathrm{g}}\right)$ and standard deviation are shown in Fig. 9. It was found that there is no large temperature difference between the high $\left(7.2^{\circ} \mathrm{C}\right)$ and low $\left(5.6^{\circ} \mathrm{C}\right)$ temperature groups. It can be concluded that the common characteristics of the low-temperature group are: low temperature setting (in $86 \%$ of cases), door openings $<20$ times/day $(100 \%)$ and a refrigerator that is not built-in. The common characteristics of the high-temperature group are: builtin (in $79 \%$ of cases), high temperature setting $(61 \%)$ and door openings $>20$ times/day $(58 \%)$.

\subsubsection{Segmentation}

The refrigerators were divided into subgroups using explanatory variables (Fig. 10). The frequency of door openings (FDO) was the best criterion enabling division of the 112 refrigerators into 2 subgroups. Subdivision was then continued successively to the greatest possible extent. At the bottom level, the overall temperature and the number of samples are reported.

The highest temperature group $\left(8.1^{\circ} \mathrm{C}\right)$ has the highest number of door opening $>20$ times/day (FDO 3) and low temperature settings (TS 1). The lowest temperature group $\left(5.1{ }^{\circ} \mathrm{C}\right)$ has less door openings $<20$ times/day (FDO 1,2$)$, high temperature settings (TS 4, 5) and the refrigerator is not near a heat source (HS 2).

\section{Conclusions}

The survey was carried out in France on 143 families during April to June 1999, but only 119 refrigeratortemperature files could be used. It was shown that $36 \%$ of families were unaware of the refrigerating system 


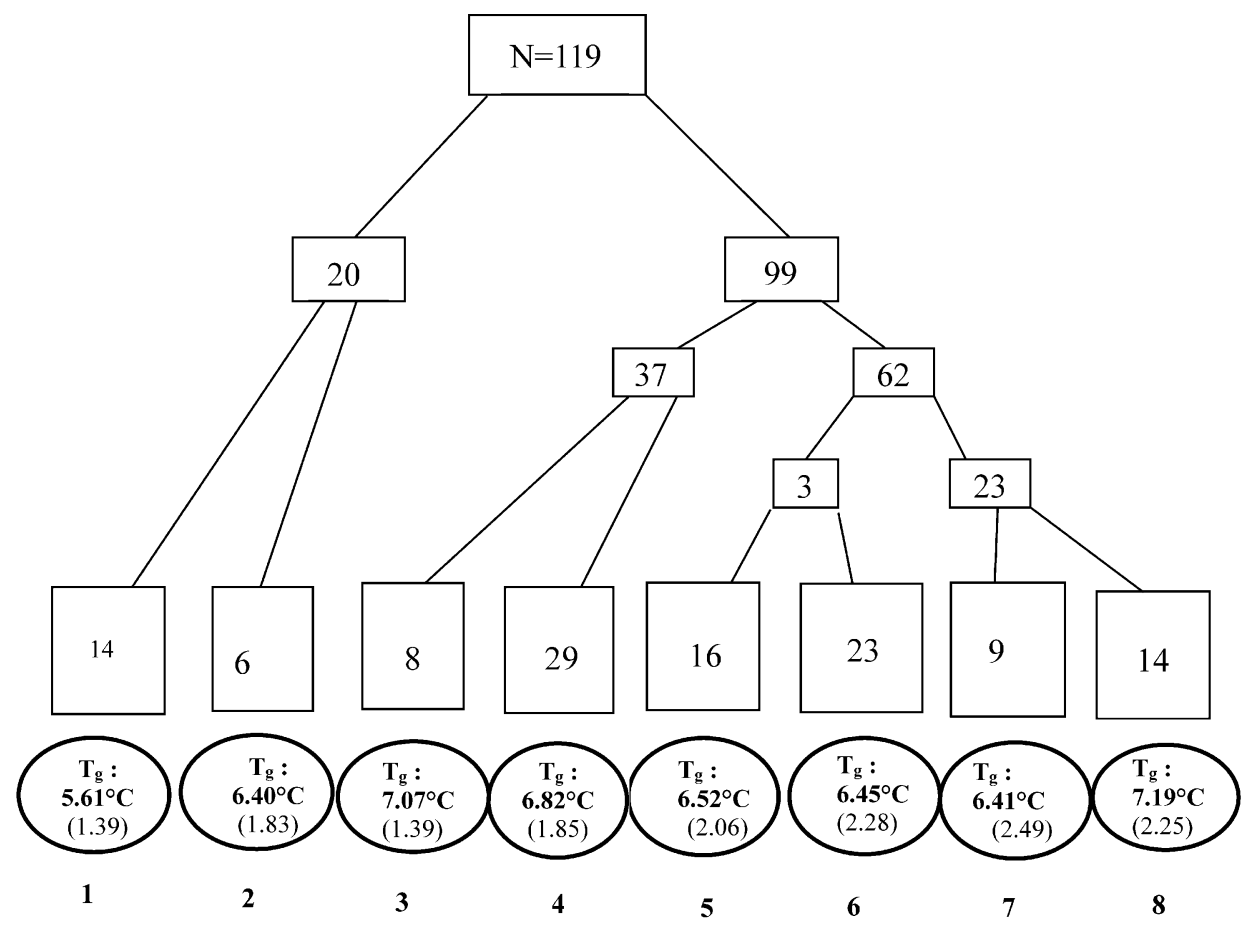

Fig. 9. Clustering representing the number of refrigerators in each group, the overall temperature $\left(T_{\mathrm{g}}\right)$ and the standard deviation value (in brackets).

Fig. 9. Arbre de classification représentant le nombre de réfrigérateurs dans chaque groupe, la température globale ( $\left.T_{g}\right)$ et l'écart-type (entre parenthèses).

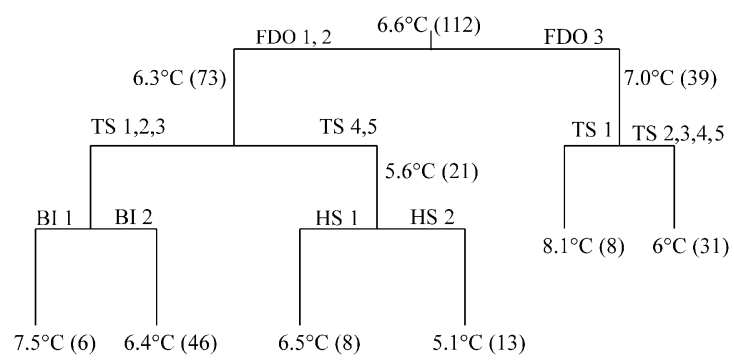

Fig. 10. Segmentation representing the average temperature and the number of samples (in brackets).

Fig. 10. Segmentation représentant la température moyenne et le nombre d'échantillons (entre parenthèses).

(static or ventilation) of their refrigerator. Seventy per cent of families set their thermostat at "less cold" positions (less than $50 \%$ of the maximum level). This may be for energy-consumption reasons or in order to achieve preferred consumption temperatures for certain foods without awareness of food safety.

The temperature of $26 \%$ of surveyed refrigerators is higher than $8{ }^{\circ} \mathrm{C}$, which is the regulatory temperature for stable foods in France. The difference between the temperature level during weekdays and weekends is not significant.
The comparison of temperature measured using a thermometer at a given moment and using a data logger over a 7-day period shows that statistically there is no relationship between these two temperatures. This means that the temperature measured using a thermometer does not represent the true operating conditions of the refrigerator.

When the temperature data are analysed for all refrigerators without distinction of the type, it was observed that the difference between the mean temperature measured using a data logger at the top, middle and bottom of the refrigerator compartment is not significant. However, when the analysis was performed for each type, it was found that the temperature heterogeneousness observed to the greatest extent in the type-D models. For this type of refrigerator, the consumer thus needs to know the location of "cold" and "hot" zones, enabling food to be kept in the right zone. Information campaigns, explanatory brochures and providing of thermometers are helpful in educating consumers in efficient use of their refrigerators.

This study shows that the combination of the use conditions (temperature setting, frequency of door openings, heat sources and built-in) seems to have a major impact on the refrigerator temperature. 
Furthermore, the effect of other parameters such as the degree of loading and the product arrangement in the refrigerator compartment is of interest. Moreover, more information may be obtained if all recorded temperatures are used in the analysis, instead of mean values.

\section{Acknowledgements}

The authors would like to thank the General Food Division (French Ministry of Agriculture) and the General Competition, Consumption and Fraud Prevention Division (French Ministry of Finance) for their financial support. The authors would like to thank also the CREDOC for the offer of consumer panel and the suppliers of data loggers (Testo, Sopac Thermocontrol, Groupe Befic, Jules Richard Instruments, Groeneveld) for the loan of materials.

\section{References}

[1] Flynn OM, Blair I, McDowell D. The efficiency and consumer operation of domestic refrigerators. Int $\mathrm{J}$ Refrig 1992;15(5):307-12.

[2] James SJ, Evans J. Consumer handling of chilled foods: temperature performances. Int J Refrig 1992;15:299-306.

[3] Victoria R. Ne joves pas avec le froid. 50 millions de consommateur 1993;267:36-7.

[4] Lezenne Coulander de PA, Koelkast temperature thuis. Report of the regional Inspectorate for Health Protection, Leeuwarden, The Netherlands, 1994.

[5] O'Brien GD. Domestic refrigerator air temperatures and the public's awareness of refrigerator use. Int J Environ Health Res 1997;7:141-8.

[6] Sergelidis D, Abrahim A, Sarimvei A, Panoulis C, Karaioannoglou $\mathrm{P}$, Genigeorgis $\mathrm{C}$. Temperature distribution and prevalence of Listeria spp. in domestic, retail and industrial refrigerators in Greece. Int J Food Microbiol 1997;34:171-7.

[7] Shixiong B, Jing X. Testing of home refrigerators and measures to improve their performance. IIR-Commissions B2, C2, D2/3 -Dresden (Germany) 1990; p. 411-5. 